Victorian Society objected to certain aspects of the plans which would, in the view of the chancellor, if upheld, require a 'wholesale rethink' of the proposals. The Victorian Society, which had objected to the proposals during the planning permission application, argued that the grant of planning permission should not be determinative as the considerations thereunder were not the same as for listed building consent, which was not required due to the ecclesiastical exemption. The chancellor nevertheless went on to consider the fact that the Victorian Society had unsuccessfully made the same objections at the planning permission stage. The faculty was granted. [RA]

doi:10.1017/So956618X11000251

\title{
Re St Mary Magdalene, Reigate
}

Southwark Consistory Court: Petchey Ch, September 2010

Reordering - relocation of rood screen - secular system - Bishopsgate questions

The petitioners (the incumbent and churchwardens) sought a faculty for a major re-ordering of the grade II* listed parish church. The proposals included the relocation of the central section of the rood screen and the removal and disposal of pews. English Heritage raised no objection to the proposals. The DAC recommended the works, having consulted the (then) Council for the Care of Churches. A number of letters of objection were received from individuals. The Society for the Protection of Ancient Buildings objected to the relocation of the central section of the rood screen. The Victorian Society, in addition to objecting to that aspect of the proposals, objected to the removal of the nave pews. The local authority also objected on those two grounds. SPAB and the Victorian Society became parties opponent. The petition was determined on consideration of written representations under rule 26(1) of the Faculty Jurisdiction Rules 2000. In a judgment extending to 79 pages the chancellor carried out a thorough survey of government policy and guidance in respect of the historic environment, including in particular Planning Policy Statement 5 (2010) and what it said about to the need to recognise both that 'heritage assets' were a 'nonrenewable resource' and that 'intelligently managed change may sometimes be necessary'. The chancellor also considered the principles that lay behind the ecclesiastical exemption and, in particular, the principle that it would be operated on a basis that was 'no less strict' than the secular system of listed building control. He concluded that the principles enunciated by the ecclesiastical courts do not lead to authorisations that would not properly be available in the secular sphere. In particular, the balancing exercise enjoined by the third of the Bishopsgate questions involved giving greater weight to the heritage asset the 
more significant it was. The chancellor held that on the evidence the rood screen - although it had been subject to restoration in the nineteenth century - did retain a majority of original, mediaeval work and that it was 'still evidently very significant'. Applying the Bishopsgate questions, the chancellor held that a faculty should not be granted to permit the removal and relocation within the church of the central section of the rood screen. Having been installed in its current location in the fifteenth century, it was a 'remarkable survival' and unique within Surrey. It contributed substantially to the character of the church building and relocating its central section would destroy its integrity. The need for change that had been shown - the improvement of sight lines and the removal of a physical separation between worshippers in a large and growing church - did not outweigh the severe harm that the proposals relating to the screen would involve. The pews, by contrast, were not 'particularly special' and they could, in principle, be removed. The chancellor was not satisfied about the detail of the proposals for the chairs that would replace them. Accordingly, the chancellor made his judgment an interim judgment so that further material could be submitted to the court concerning the seating, following a meeting of interested parties. [Alexander McGregor]

\section{Re Holy Trinity, Richmond}

Southwark Consistory Court: Petchey Ch, October 2010 Memorial tablet - artistic adornment - reference to grandparents

A faculty was sought for the installation of a memorial tablet to the late David Church OBE, to be paid for by his widow. The tablet was to be a simple square of Portland stone located with other memorial tablets in the north aisle. The wording was to include reference to the marriage of Mr Church's grandparents at the church on 29 April 1890 . The DAC recommended several alterations to the design and certified 'no objection' to the proposal on some of those being met. The chancellor had no doubt that Mr Church was deserving of the 'privilege' of commemoration by memorial tablet. He referred to the Chancellor's Guidance on Churchyards and Memorials, which state that a faculty would not generally be granted unless, inter alia, the memorial is artistically an adornment to the church. He found that the proposed design would not be an 'artistic adornment' due to its simplicity, although he stated that a simple design is not necessarily incompatible with an artistic adornment. He held that there must be 'good reason' for permitting an exception to the Guidance. The chancellor identified three such reasons, none of which applied here: 